\title{
How Do Observational Scales Correlate the Ratings of Children's Behavior during Pediatric Procedural Sedation?
}

\author{
Larissa da Silva Moura, ${ }^{1}$ Paulo Sucasas Costa, ${ }^{2}$ and Luciane Rezende Costa \\ ${ }^{1}$ Health Sciences Graduate Program, Faculdade de Medicina, Universidade Federal de Goiás (UFG), Goiânia, GO, Brazil \\ ${ }^{2}$ Faculty of Medicine, UFG, Goiânia, GO, Brazil \\ ${ }^{3}$ Faculty of Dentistry, Faculdade de Odontologia, UFG, Goiânia, GO, Brazil
}

Correspondence should be addressed to Luciane Rezende Costa; lsucasas@ufg.br

Received 7 September 2016; Accepted 7 December 2016

Academic Editor: Jareen K. Meinzen-Derr

Copyright (C) 2016 Larissa da Silva Moura et al. This is an open access article distributed under the Creative Commons Attribution License, which permits unrestricted use, distribution, and reproduction in any medium, provided the original work is properly cited.

\begin{abstract}
Background. There is little information regarding the ability of observational scales to properly assess children's behavior during procedural sedation. Aim. To evaluate the characteristics of the Houpt scales, the Ohio State University Behavioral Rating Scale (OSUBRS) and the Venham Behavior Rating Scale when applied to preschool children undergoing conscious dental sedation. Design. This study included 27 children, 4-6 years old with early childhood caries that participated in a clinical trial (NCT02284204) that investigated two sedative regimes using oral midazolam/ketamine. Dental appointments were video-recorded; five calibrated observers assessed 1,209 minutes of video recording to score the children's behavior, following the instructions of the investigated scales. Data were analyzed by descriptive analysis and Spearman correlation tests $(P<0.05)$. Results. The Houpt overall behavior and the Venham scale were highly correlated (rho $=-0.87 ; P<0.001)$. OSUBRS scores were better correlated with Houpt overall behavior and Venham ratings, when compared to Houpt scores in the categories for movement and crying. Conclusions. The Houpt overall behavior and the Venham scores are global scales that properly measure children's behavior during dental sedation. Continuous assessment with OSUBRS through videos has a chance to give more precise data, while the Houpt categories can easily demonstrate children's behavior during procedures.
\end{abstract}

\section{Introduction}

In recent years, moderate (conscious) sedation for pediatric dental treatment has shown success rates varying between $26.7 \%$ [1] and $95.0 \%$ [2], which are primarily influenced by the characteristics of the child, sedative regimen, type of dental procedure, and methods for assessing the child's behavior.

One of the variables determining the success of conscious dental sedation is the child behavior during the procedure. According to recent clinical trials [1-20] (Table 1), the Houpt scale [21] and the Ohio State University Behavioral Rating Scale (OSUBRS) [22] have been frequently used for this purpose. Another scale, the Venham Behavior Rating Scale [23] was initially proposed for evaluating general pediatric dental treatment but has also been used during dental sedation procedures [15].
The Houpt scale (Table 2) was first proposed in 1985 in a clinical study without a thorough investigation of its properties [21]. Researchers had observed a degree of concordance between crying and movement and measured $90 \%$ reliability in a test-retest analysis. The Houpt scale is advantageous because it categorizes the assessment of the severity of behavioral expressions (sleep, movement, and crying), thereby increasing the possibility to detect specific changes in a child's behavior [24]. However, this scale has the potential disadvantage of requiring sufficient examiner skill to detect and appropriately assign scores for different categories while witnessing a care session, which could be minimized by video-recording the dental consultation to allow subsequent evaluation of the child's behavior [24]. Still, the Houpt scales have good interrater agreement when observers have more or less experience [25]. 
TABLE 1: Randomized, controlled clinical trials on pediatric dental sedation (2011-2016).

\begin{tabular}{|c|c|c|c|c|c|}
\hline Citation & Participants & Sedative regime & Dental procedure & Behavioral outcomes & Results/conclusions \\
\hline $\begin{array}{l}\text { Malhotra et al., } 2016 \\
\text { [3] }\end{array}$ & $\begin{array}{c}36 \text { children, 3-9 years } \\
\text { old }\end{array}$ & $\begin{array}{c}\text { MK: saline IN and } \\
\text { midazolam } \\
(0.5 \mathrm{mg} / \mathrm{kg}) \text { PO with } \\
\text { ketamine }(5 \mathrm{mg} / \mathrm{kg}) \\
\text { mixed in mango juice } \\
\text { DX: } \\
\text { dexmedetomidine } \\
(1 \mu \mathrm{g} / \mathrm{kg}) \text { IN and } \\
\text { mango juice } \\
\text { C: saline IN and } \\
\text { mango juice }\end{array}$ & Unclear & $\begin{array}{l}\text { Sedation level and } \\
\text { behavior score } \\
\text { (modified observer } \\
\text { assessment of } \\
\text { alertness and } \\
\text { sedation, MOAAS) } \\
\text { Ease of treatment } \\
\text { completion (Houpt } \\
\text { scale) }\end{array}$ & $\begin{array}{l}\text { MK: } 75.0 \% \text { patients } \\
\text { successfully sedated; } \\
\text { DX, } 53.9 \% \text {; C, none } \\
\text { Houpt scores were } \\
\text { higher in MK than } \\
\text { DX }\end{array}$ \\
\hline $\begin{array}{l}\text { Flores-Castillo et al., } \\
2015 \text { [4] }\end{array}$ & $\begin{array}{l}13 \text { children, } \\
17-46 \text { months old }\end{array}$ & $\begin{array}{c}\text { A: midazolam } \\
(0.4 \mathrm{mg} / \mathrm{kg}) \mathrm{SC} \\
\mathrm{B}: \\
\text { midazolam-ketamine } \\
(0.4 \text { and } 0.1 \mathrm{mg} / \mathrm{kg}) \\
\mathrm{SC}\end{array}$ & $\begin{array}{l}\text { Procedures with local } \\
\text { anesthesia }\end{array}$ & $\begin{array}{l}\text { Behavior (modified } \\
\text { Houpt scale) }\end{array}$ & $\begin{array}{c}\text { Group A: } 53.85 \% \text { (no } \\
\text { cry and no } \\
\text { movement) } \\
\text { Group B: } 69.23 \% \text { (cry } \\
\text { and movement that } \\
\text { not interfere with } \\
\text { treatment) }\end{array}$ \\
\hline Salem et al., 2015 [5] & $\begin{array}{l}88 \text { children, } \\
4-7 \text { years old }\end{array}$ & $\begin{array}{l}\text { Midazolam }(0.2 \text { or } \\
0.5 \mathrm{mg} / \mathrm{kg}) \mathrm{PO} \\
\text { A: PO formulation } \\
\text { B: IV formulation }\end{array}$ & $\begin{array}{l}\text { Pulp therapy in } \\
\text { primary molars }\end{array}$ & $\begin{array}{l}\text { Behavior (North } \\
\text { Carolina and Houpt } \\
\text { scale) }\end{array}$ & $\begin{array}{c}\text { Acceptable behavior } \\
\text { in } 90.9 \%(\mathrm{~A}) \text { and } \\
79.5 \%(\mathrm{~B})\end{array}$ \\
\hline $\begin{array}{l}\text { Mahmoud and } \\
\text { Haggag, } 2014 \text { [6] }\end{array}$ & $\begin{array}{l}30 \text { children, } \\
4-8 \text { years old }\end{array}$ & $\begin{array}{c}\text { A: dexmedetomidine } \\
(2.5 \mathrm{mcg} / \mathrm{kg}) \mathrm{PO} \\
\text { B: midazolam } \\
(0.5 \mathrm{mg} / \mathrm{kg}) \mathrm{PO}\end{array}$ & $\begin{array}{c}\text { Procedures with local } \\
\text { anesthesia }\end{array}$ & $\begin{array}{l}\text { Behavior (modified } \\
\text { Houpt scale) }\end{array}$ & $\begin{array}{c}\text { Median Houpt scores } \\
\text { were } 4(\mathrm{~A}) \text { and } 3(\mathrm{~B})\end{array}$ \\
\hline Ghajari et al., 2014 [7] & $\begin{array}{l}16 \text { children, } \\
2-6 \text { years old }\end{array}$ & $\begin{array}{c}\text { A: midazolam } \\
(0.5 \mathrm{mg} / \mathrm{kg})+ \\
\text { hydroxyzine } \\
(1 \mathrm{mg} / \mathrm{kg}) \text { PO } \\
\text { B: chloral hydrate } \\
(50 \mathrm{mg} / \mathrm{kg})+ \\
\text { hydroxyzine } \\
(1 \mathrm{mg} / \mathrm{kg}) \text { PO }\end{array}$ & Not cited & $\begin{array}{c}\text { Behavior (Houpt } \\
\text { scale) }\end{array}$ & $\begin{array}{l}\text { Groups differed in } \\
\text { sedation success: A: } \\
64.3 \% \text {; B: } 33.3 \%\end{array}$ \\
\hline $\begin{array}{l}\text { Natarajan Surendar et } \\
\text { al., } 2014 \text { [8] }\end{array}$ & $\begin{array}{l}84 \text { children, } \\
4-14 \text { years old }\end{array}$ & $\begin{array}{c}\text { D1: dexmedetomidine } \\
(1 \mathrm{mcg} / \mathrm{kg}) \text { IN } \\
\text { D2: } \\
\text { dexmedetomidine } \\
(1.5 \mathrm{mcg} / \mathrm{kg}) \text { IN } \\
\text { M1: midazolam } \\
(0.2 \mathrm{mg} / \mathrm{kg}) \text { IN } \\
\text { K1: ketamine } \\
(5 \mathrm{mg} / \mathrm{kg}) \text { IN } \\
\end{array}$ & Teeth extractions & $\begin{array}{c}\text { Behavior (author's } \\
\text { scale) } \\
\text { Pain (the FLACC Pain } \\
\text { Assessment Tool) }\end{array}$ & $\begin{array}{c}\text { Success: D2 }(85.7 \%) \\
\text { D1 (81\%), K1 (66.7\%), } \\
\text { M1 }(61.9 \%)\end{array}$ \\
\hline Sheta et al., 2014 [9] & $\begin{array}{l}72 \text { children, } \\
3-6 \text { years old }\end{array}$ & $\begin{array}{c}\text { A: midazolam } \\
(0.2 \mathrm{mg} / \mathrm{kg}) \text { IN } \\
\text { B: dexmedetomidine } \\
(1 \mu \mathrm{g} / \mathrm{kg}) \text { IN }\end{array}$ & Dental rehabilitation & $\begin{array}{l}\text { Sedation status (no } \\
\text { specific scale) }\end{array}$ & $\begin{array}{c}\text { Children sedation: } \\
\text { A: } 44.4 \% \\
\text { B: } 77.8 \%\end{array}$ \\
\hline $\begin{array}{l}\text { Azevedo et al., } 2013 \\
{[10]}\end{array}$ & $\begin{array}{l}10 \text { children, } \\
2-4 \text { years old }\end{array}$ & $\begin{array}{c}\text { Midazolam in } \\
\text { different doses }(0.2 \text { to } \\
0.4 \mathrm{mg} / \mathrm{kg}) \text { PO } \\
\text { placebo PO }\end{array}$ & Dental rehabilitation & $\begin{array}{c}\text { Behavior (Frankl } \\
\text { scale), Adequacy of } \\
\text { sedation (Ramsay } \\
\text { scale) }\end{array}$ & $\begin{array}{l}\text { All midazolam doses } \\
\text { allowed positive } \\
\text { behavior and longer } \\
\text { appointments } \\
\text { Midazolam: } 58.1 \% \\
\text { Placebo: } 31.0 \% \\
\end{array}$ \\
\hline Chopra et al., 2013 [11] & $\begin{array}{l}30 \text { children, } \\
2-8 \text { years old }\end{array}$ & $\begin{array}{c}\text { A: midazolam } \\
(0.25 \mathrm{mg} / \mathrm{kg}) \mathrm{MB} \\
\text { spray } \\
\text { B: midazolam } \\
(0.25 \mathrm{mg} / \mathrm{kg}) \mathrm{IN}\end{array}$ & $\begin{array}{c}\text { Procedure with local } \\
\text { anesthesia }\end{array}$ & $\begin{array}{c}\text { Behavior (Houpt } \\
\text { scale) } \\
\text { Acceptability of } \\
\text { administration route }\end{array}$ & $\begin{array}{l}\text { The acceptance in A } \\
\text { was better than in } \mathrm{B} \text {. } \\
\text { There was no } \\
\text { difference in behavior } \\
\text { scores }\end{array}$ \\
\hline
\end{tabular}


TABLe 1: Continued.

\begin{tabular}{|c|c|c|c|c|c|}
\hline Citation & Participants & Sedative regime & Dental procedure & Behavioral outcomes & Results/conclusions \\
\hline Mittal et al., 2013 [12] & $\begin{array}{l}40 \text { children, } \\
2-6 \text { years old }\end{array}$ & $\begin{array}{c}\text { Premedication: } \\
\text { midazolam } \\
(0.5 \mathrm{mg} / \mathrm{kg}) \mathrm{PO} \\
\text { Intervention: } \\
\text { A: propofol } \\
(1-1.5 \mathrm{mg} / \mathrm{kg}) \mathrm{IV} \\
\text { B: ketofol (1-1.5 mg/kg } \\
\text { midazolam + } \\
0.25 \mathrm{mg} / \mathrm{kg} \text { ketamine }) \\
\text { IV } \\
\text { Maintenance: } \\
\text { propofol } \\
\text { (25-75 mg/kg/min) } \\
\text { IV (bolus if needed) }\end{array}$ & $\begin{array}{l}\text { Pulpectomy in } \\
\text { primary molars }\end{array}$ & $\begin{array}{l}\text { Behavior: procedural } \\
\text { success, operator } \\
\text { satisfaction, quality of } \\
\text { sedation } \\
\text { Also duration of } \\
\text { treatment, recovery } \\
\text { time, total dose of } \\
\text { propofol }\end{array}$ & $\begin{array}{c}\text { Other analysis } \\
\text { showed no behavior } \\
\text { differences between } \\
\text { groups }\end{array}$ \\
\hline $\begin{array}{l}\text { Moreira et al., } 2013 \\
{[13]}\end{array}$ & $\begin{array}{l}41 \text { children, } \\
<3 \text { years old }\end{array}$ & $\begin{array}{c}\text { A: midazolam } \\
(0.5 \mathrm{mg} / \mathrm{kg}) \mathrm{PO}+ \\
\text { ketamine }(3 \mathrm{mg} / \mathrm{kg}) \\
\text { PO } \\
\text { B: midazolam } \\
(1.0 \mathrm{mg} / \mathrm{kg}) \text { PO } \\
\text { C: placebo PO }\end{array}$ & $\begin{array}{l}\text { Procedures under } \\
\text { local anesthesia and } \\
\text { protective } \\
\text { stabilization }\end{array}$ & Behavior (OSUBRS) & $\begin{array}{l}\text { Group A was } \\
\text { associated with more } \\
\text { cooperative behavior } \\
\text { and a longer session }\end{array}$ \\
\hline $\begin{array}{l}\text { Toomarian et al., } 2013 \\
\text { [1] }\end{array}$ & $\begin{array}{l}30 \text { children, } \\
2-6 \text { years old }\end{array}$ & $\begin{array}{l}\text { Crossover design } \\
\text { hydroxyzine } \\
(1 \mathrm{mg} / \mathrm{kg}) \mathrm{PO} \\
\text { associated with: } \\
\text { A: meperidine } \\
(2 \mathrm{mg} / \mathrm{kg}) \mathrm{PO} \\
\mathrm{B}: \mathrm{meperidine} \\
(1 \mathrm{mg} / \mathrm{kg}) \mathrm{SM} \\
\text { C: } \mathrm{midazolam} \\
0.5 \mathrm{mg} / \mathrm{kg} \text { PO }\end{array}$ & $\begin{array}{l}\text { Pulp therapy in } \\
\text { primary teeth }\end{array}$ & $\begin{array}{l}\text { Behavior (Houpt and } \\
\text { modified Houpt) }\end{array}$ & $\begin{array}{c}\text { Success rates: } \\
\text { A: } 46.7 \% \text {; B: } 50 \% \text {; C: } \\
26.7 \% \\
\text { Patients } \geq 4 \text { years old } \\
\text { had six times greater } \\
\text { chance of success }\end{array}$ \\
\hline Tyagi et al., 2013 [14] & $\begin{array}{l}40 \text { children, } \\
2-6 \text { years old }\end{array}$ & $\begin{array}{c}\text { Parallel design } \\
\text { A: midazolam } \\
(0.5 \mathrm{mg}) \text { PO } \\
\text { B: diazepam }(0.5 \mathrm{mg}) \\
\text { PO } \\
\text { C: midazolam } \\
(0.06 \mathrm{mg} / \mathrm{kg}) \mathrm{IV} \\
\text { D: placebo PO }\end{array}$ & $\begin{array}{c}\text { Restorations, pulp } \\
\text { therapy, extractions, } \\
\text { local anesthesia when } \\
\text { necessary }\end{array}$ & $\begin{array}{l}\text { Behavioral changes } \\
\text { (Houpt scale) }\end{array}$ & $\begin{array}{c}\text { Groups A and B: } \\
\text { Similar sedative } \\
\text { effects. Group C } \\
\text { showed better scores } \\
\text { in behavior. Group D: } \\
\text { more negative } \\
\text { behavior Midazolam } \\
\text { was better than } \\
\text { diazepam }\end{array}$ \\
\hline $\begin{array}{l}\text { Collado et al., } 2013 \\
{[15]}\end{array}$ & $\begin{array}{l}98 \text { patients, } \\
7-15 \text { years old }\end{array}$ & $\begin{array}{c}\text { A: patients with } \\
\text { intellectual disability } \\
\text { (ID, 33) } \\
\text { B: Dentally anxious } \\
\text { patients (DA, } 44) \\
\text { Midazolam (0.3 to } \\
0.5 \mathrm{mg} / \mathrm{kg} \text { ) IV with or } \\
\text { without inhalation } \\
\text { sedation }(50 \% \\
\left.\mathrm{N}_{2} \mathrm{O} / \mathrm{O}_{2}\right) \\
\end{array}$ & Not cited & $\begin{array}{c}\text { Success rate, level of } \\
\text { cooperation } \\
\text { (Venham), level of } \\
\text { sedation (Ramsay } \\
\text { scale) }\end{array}$ & $\begin{array}{l}\text { In patients with DA } \\
\text { and ID, more sessions } \\
\text { were conducted with } \\
\text { a totally relaxed } \\
\text { patient (Venham } \\
\text { score of 0) } \\
\text { Success rate: } \\
\text { A: } 89.1 \% \\
\text { B: } 90.6 \%\end{array}$ \\
\hline $\begin{array}{l}\text { Bhatnagar et al., } 2012 \\
\text { [16] }\end{array}$ & $\begin{array}{l}60 \text { children, } \\
3-9 \text { years old }\end{array}$ & $\begin{array}{c}\text { Parallel design } \\
\text { A: midazolam } \\
(0.5 \mathrm{mg} / \mathrm{kg}) \mathrm{PO} \\
\text { B: tramadol }(2 \mathrm{mg} / \mathrm{kg}) \\
\text { PO } \\
\text { C: triclofos } \\
\text { (70 mg/kg) PO } \\
\text { D: zolpidem } \\
(0.4 \mathrm{mg} / \mathrm{kg}) \text { PO } \\
\end{array}$ & Not cited & $\begin{array}{c}\text { Level of sedation (no } \\
\text { scale) and ease of } \\
\text { handling }\end{array}$ & $\begin{array}{l}\text { Groups A and B } \\
\text { achieved better levels } \\
\text { of sedation. D showed } \\
\text { worse cooperation. } \\
\text { Midazolam produced } \\
\text { the best results, } \\
\text { similar to tramadol }\end{array}$ \\
\hline
\end{tabular}


TABLE 1: Continued.

\begin{tabular}{|c|c|c|c|c|c|}
\hline Citation & Participants & Sedative regime & Dental procedure & Behavioral outcomes & Results/conclusions \\
\hline $\begin{array}{l}\text { Guelmann et al., } 2012 \\
\text { [17] }\end{array}$ & $\begin{array}{l}17 \text { children, } \\
5-8 \text { years old }\end{array}$ & $\begin{array}{c}\text { A: discontinuation of } \\
\text { nitrous oxide after } \\
\text { local anesthesia ( } 100 \% \\
\left.\mathrm{O}_{2}\right) \\
\text { B: Constant nitrous } \\
\text { oxide }(50 \% \text { de } \\
\left.\mathrm{N}_{2} \mathrm{O} / 50 \% \mathrm{O}_{2}\right)\end{array}$ & $\begin{array}{c}\text { Restorative } \\
\text { procedures, lower } \\
\text { arch }\end{array}$ & Behavior (OSUBRS) & $\begin{array}{c}\text { There were no } \\
\text { differences between } \\
\text { groups }\end{array}$ \\
\hline Somri et al., 2012 [18] & $\begin{array}{l}90 \text { children, } \\
3-10 \text { years old }\end{array}$ & $\begin{array}{l}\text { Midazolam PO } \\
\text { administered in one } \\
\text { of } 3 \text { doses: } \\
\text { A: } 0.5 \mathrm{mg} / \mathrm{kg} \\
\text { B: } 0.75 \mathrm{mg} / \mathrm{kg} \\
\text { C: } 1 \mathrm{mg} / \mathrm{kg}\end{array}$ & General procedures & $\begin{array}{c}\text { Behavior (Houpt } \\
\text { scale) } \\
\text { Sedation level } \\
\text { (Wisconsin sedation } \\
\text { scale) } \\
\text { Completion of } \\
\text { procedures } \\
\end{array}$ & $\begin{array}{l}\text { Sedation scores, } \\
\text { cooperation, } \\
\text { completion of the } \\
\text { procedure were } \\
\text { higher in B and C } \\
\text { than in A }\end{array}$ \\
\hline $\begin{array}{l}\text { Bahetwar et al., } 2011 \\
\text { [19] }\end{array}$ & $\begin{array}{l}45 \text { children, } \\
2-6 \text { years old }\end{array}$ & $\begin{array}{c}\text { A: midazolam } \\
(0.3 \mathrm{mg} / \mathrm{kg}) \mathrm{IN} \\
\text { B: ketamine }(6 \mathrm{mg} / \mathrm{kg}) \\
\text { IN } \\
\text { C: midazolam + } \\
\text { ketamine }(0.2 \mathrm{mg} / \mathrm{kg} \\
4 \mathrm{mg} / \mathrm{kg}) \mathrm{IN}\end{array}$ & $\begin{array}{l}\text { Procedures under } \\
\text { local anesthesia } \\
\text { (infiltrative or block) }\end{array}$ & Success of treatment & $\begin{array}{c}\text { Quicker sedation } \\
\text { onset in B } \\
\text { Success rates: } \\
\text { A: 69.0\%; B: } 89.0 \% \text {; C: } \\
84.0 \%\end{array}$ \\
\hline Pandey et al., 2011 [2] & $\begin{array}{l}34 \text { children, } \\
2-6 \text { years old }\end{array}$ & $\begin{array}{l}\text { Ketamine }(6 \mathrm{mg} / \mathrm{kg}) \\
\text { IN administered with } \\
\text { atomizer }(\mathrm{A}) \text { and } \\
\text { dropper }(\mathrm{B})\end{array}$ & $\begin{array}{l}\text { Procedures under } \\
\text { local anesthesia } \\
\text { (infiltrative or block) }\end{array}$ & $\begin{array}{l}\text { Success of sedation, } \\
\text { behavior during } \\
\text { administration and } \\
\text { treatment, onset, } \\
\text { sedation depth, } \\
\text { recovery time }\end{array}$ & $\begin{array}{c}\text { Sedation was } \\
\text { successful in } 84 \%(\mathrm{~B}) \\
\text { to } 95 \%(\mathrm{~A}) \\
\text { Group A had quicker } \\
\text { onset and recovery } \\
\text { time after sedation }\end{array}$ \\
\hline $\begin{array}{l}\text { Shabbir et al., } 2011 \\
{[20]}\end{array}$ & $\begin{array}{l}12 \text { children, } \\
3-9 \text { years old }\end{array}$ & $\begin{array}{l}\text { A: triclofos } \\
(70 \mathrm{mg} / \mathrm{kg}) \text { PO } \\
\text { B: midazolam } \\
(0.5 \mathrm{mg} / \mathrm{kg}) \text { PO }\end{array}$ & $\begin{array}{l}\text { Procedures under } \\
\text { local anesthesia }\end{array}$ & $\begin{array}{l}\text { Behavior (Houpt } \\
\text { scale) }\end{array}$ & $\begin{array}{c}\text { Midazolam was more } \\
\text { efficacious than } \\
\text { triclofos }\end{array}$ \\
\hline
\end{tabular}

$\mathrm{IN}=$ intranasal route; $\mathrm{IV}=$ intravenous route; $\mathrm{MB}=$ buccal route; $\mathrm{SM}=$ submucous route $\mathrm{PO}=$ oral route; $\mathrm{SC}=$ subcutaneous route; $\mathrm{OSUBRS}=\mathrm{Ohio}$ State University Behavioral Rating Scale; $\mathrm{N}_{2} \mathrm{O}=$ nitrous oxide; $\mathrm{O}_{2}=$ oxygen.

The OSUBRS [22] captures mutually exclusive behaviors (Table 2); the presentation of its results is given by the percentage of a given score observed during a session of dental treatment requiring sedation [24], increasing the chance of a more accurate evaluation. However, it requires specific software to achieve this goal.

The Venham Behavior Rating Scale was developed to evaluate children's behavior during dental treatment to overcome the difficulties related to reliability, validity, and the measurement properties of existing scales at that time [23]. The Venham scale presents significant advantages as raters can be readily trained to use the scale, and it is easily integrated into clinical activities and research designs. The original scale has 6 scores, while the Brazilian version has 5 resulting from the merger of ratings 2 and 3 [26] (Table 3). This is the only one of the three scales investigated here that was systematically cross-culture adapted to BrazilianPortuguese populations.

Of the 20 clinical trials cited in Table 1 eleven used the Houpt scale, three used the OSUBRS, and one the Venham scale. So, how can one compare successful outcomes achieved through different measures? From a clinical perspective, it is important to know if different sedative protocols work well in practice and to have a tool that easily and securely assesses children's behavior on a day-byday basis. In the context of investigations, the operationalization of children's behavior assessment during sedation has been an issue because it is desirable to have the training and the blinding of observers to accomplish accurate evaluations.

Because of the variety of behavior assessment scales for pediatric dental sedation it is difficult to compare studies in a systematic review and then guide the clinician through the evidence revealed about this topic [27]. One study investigated the correlation of four scales in assessing children's behavior during the dental treatment (the Houpt and Frankl scales, the Global Rating Scale, and the Visual Analogue Scale). The Houpt scale demonstrated agreement among dentists and was recommended to assess behavior related to specific procedures [25]. There is a lack of studies comparing observational scales that assess children's behavior during dental treatment, especially in sedated children. The aim of this study was to evaluate the correlation of the scores of frequently used scales, Houpt, OSUBRS, and Venham, that assess the behavior of preschool children during sedation for dental procedures. 
TABLE 2: Houpt and OSUBRS scales [21, 22].

\begin{tabular}{ll}
\hline Behavior & Scores \\
\hline Sleep & \multicolumn{1}{c}{ Houpt scale } \\
& (1) Fully awake, alert \\
& (2) Drowsy, disoriented \\
& (3) Asleep \\
(1) Violent, interrupting treatment & (2) Continuous, making treatment difficult \\
Movement & (3) Controllable, not interfering with treatment \\
& (4) No movement \\
\hline & (1) Hysterical, demanding attention \\
& (2) Continuous, persistent, making treatment \\
difficult \\
(3) Intermittent, mild, not interfering with \\
treatment \\
(4) No crying \\
(1) Aborted, no treatment rendered \\
(2) Poor, treatment interrupted, only partial \\
treatment completed \\
(3) Regular, treatment interrupted but eventually \\
completed \\
(4) Good, difficult, but all treatment performed \\
(5) Very good, some limited crying or movement, \\
(e.g., during anesthesia or mouth prop insertion) \\
(6) Excellent, no crying or movement
\end{tabular}

\section{Materials and Methods}

2.1. Participants and Ethical Aspects. This study is a secondary analysis of data obtained from a randomized clinical trial in which 27 children aged 4-6 years (18 boys) with early childhood caries were rendered dental treatment under moderate sedation with oral midazolam and ketamine accompanied with a dose of either sevoflurane or oxygen (approved by the Research Ethics Committee of the Universidade Federal de Goias, protocol 307/2011; NCT02284204). The study was performed in accordance with the Declaration of Helsinki and Brazilian ethical regulation. The child's legal guardian was informed about the research and authorized the participation through a consent form. All treatment was video-recorded for later analysis. The primary outcomes of the aforementioned trial have not been published so far.

2.2. Moderate Dental Sedation Procedure. Each child received a combination of oral medications: midazolam $0.5 \mathrm{mg} / \mathrm{kg}$ (maximum dose 20 mg; Dormire ${ }^{\circledR}$, Cristália Laboratory, São Paulo, Brazil); ketamine at a dose of $3.0 \mathrm{mg} / \mathrm{kg}$ (maximum 50 mg, Ketamin ${ }^{\circledR}$, Cristália Laboratory, São Paulo, Brazil). After 15 minutes, the child received either oxygen only or a mixture of oxygen and sevoflurane (Sevocris ${ }^{\circledR}$, Cristália Laboratory, São Paulo, Brazil) through a vaporizer connected to the nasal anesthesia mask at an initial concentration of
$0.1 \%$, which was increased $0.1 \%$ every 30 seconds until a final expirate concentration between $0.3 \%$ and $0.4 \%$.

After 15 minutes of nasal mask use, dental procedures commenced according to the following standardized sequence: mouth prop insertion, topical and local anesthesia administration, rubber dam isolation, and use of a handpiece. All children received restoration of a lower primary molar under local anesthesia and rubber dam.

The dental sedation procedure was continuously complemented by nonpharmacological behavior management techniques, such as distraction and "tell-show-do," as we aimed to achieve moderate sedation.

All procedures in the dental chair were fully videorecorded by digital camcorder, Handycam ${ }^{\circledR}$ HDR-PJ10 (Sony Corporation, Tokyo, Japan) for later analysis of the children's behavior. The camera was camouflaged to prevent interference with the children's behavior.

2.3. Children's Behavior Assessment. Houpt and OSUBRS scales were selected for analysis because they are widely used in pediatric dentistry; the Venham scale was chosen because it is the only one that went through a systematic process of cultural adaptation to the Brazilian context.

To increase the accuracy of the evaluation, five observers were trained in the use of the scales by watching videos of similar pediatric dental treatment sessions, which were not included in the trial. For calibration, the examiners watched the videos of three patients from this study during their dental exam (performed without sedation). The same videos were examined by a pediatric dentist with expertise in outpatient sedation, considered the gold standard to evaluate agreement between observers. Intra- and interexaminer agreement was analyzed by a weighted kappa test, obtaining satisfactory reliability values (kappa > 0.6). None of the evaluators knew which drug had been used because (1) the sedatives used in the dental sedation appointments were concealed in the aforementioned RCT (only the anesthesiologist and pediatrician knew the sedatives for emergency purposes and they did not participate in the videos assessment) and (2) the video files were named according to the code children received in the RCT, without identification of the sedatives.

Five trained observers, calibrated and masked to the intervention group, independently watched the videos on a 15 -inch computer screen and determined scores of children's behavior by following the procedures of the studies that had originally developed the scales. Houpt scores were marked in a specific spreadsheet every 15 minutes and during specific procedures (mouth prop placement, anesthesia injection, rubber dam placement, start of the high-speed handpiece use, and end of the session). For the purpose of this study, sleep scores on the Houpt scale (originally anchored 1 to 3 ) were combined into score 1 (child awake or drowsy, disoriented) and score 2 (child asleep) because the videos did not allow reliable distinguishing between an awake and a disoriented child. To allow comparisons with the other scales investigated herein, the percentage of each score reported for the Houpt categories of sleep, movement, and crying was calculated for each case. 
TABLE 3: Venham Behavior Rating Scale $[23,26]$.

\begin{tabular}{|c|c|c|c|}
\hline Score & Behavior & Description & $\begin{array}{c}\text { Brazilian version (free back translation to } \\
\text { English) }\end{array}$ \\
\hline 0 & Total cooperation & $\begin{array}{l}\text { Best possible working conditions, no } \\
\text { crying or physical protest. }\end{array}$ & $\begin{array}{l}\text { Score } 0 \text {, no protest: the child has no } \\
\text { physical protest, such as crying or body } \\
\text { movements that disturb the dentist, } \\
\text { enabling good working conditions. }\end{array}$ \\
\hline 1 & Mild protest & $\begin{array}{l}\text { Soft verbal protest or (quiet) crying as a } \\
\text { signal of discomfort, but not obstructing } \\
\text { progress. Appropriate behavior for } \\
\text { procedure, that is, slight start at injection, } \\
\text { "ow" during drilling if hurting, and so on. }\end{array}$ & $\begin{array}{l}\text { Score 1, mild protest: the child protests } \\
\text { quietly (grumbling) or contained crying } \\
\text { as a sign of discomfort. However, it does } \\
\text { not prevent the continuation of } \\
\text { treatment. }\end{array}$ \\
\hline 2 & Protest more prominent & $\begin{array}{l}\text { Both crying and hand signals. May move } \\
\text { hands around making it hard to } \\
\text { administer treatment. Protest is more } \\
\text { distracting and troublesome. However, } \\
\text { child still complies with request to } \\
\text { cooperate. }\end{array}$ & \multirow{2}{*}{$\begin{array}{l}\text { Score 2, intense protest: the child expresses } \\
\text { discomfort verbally with strong crying } \\
\text { and body movements (hands, arms, } \\
\text { heads, etc.) that interfere with the } \\
\text { performance of the procedure. However, } \\
\text { he or she still meets the requests to } \\
\text { cooperate, even if with some resistance. }\end{array}$} \\
\hline 3 & $\begin{array}{l}\text { Protest presents real } \\
\text { problem to dentist }\end{array}$ & $\begin{array}{l}\text { Complies with demands reluctantly, } \\
\text { requiring extra effort by dentist. Body } \\
\text { movement. }\end{array}$ & \\
\hline 4 & Protest disrupts procedure & $\begin{array}{c}\text { Requires that all of the dentist's attention } \\
\text { be directed toward the child's behavior. } \\
\text { Compliance is eventually achieved after } \\
\text { considerable effort by the dentist, but } \\
\text { without much actual physical restraint } \\
\text { (may require holding child's hands, or the } \\
\text { like, to start). More prominent body } \\
\text { movement. }\end{array}$ & $\begin{array}{l}\text { Score 3, more intense protest: the child } \\
\text { makes larger body movements, including } \\
\text { trunk and legs. The procedure can be } \\
\text { stopped, representing a real problem for } \\
\text { the dentist and demanding physical and } \\
\text { mental effort. Physical restraint is } \\
\text { required for part of the body (hands, } \\
\text { head). Yet the child cooperates reluctantly } \\
\text { and partially with the dentist's } \\
\text { commands. }\end{array}$ \\
\hline 5 & General protest & $\begin{array}{l}\text { No compliance or cooperation. Physical } \\
\text { restraint is required. }\end{array}$ & $\begin{array}{l}\text { Score 4, general protest: no cooperation } \\
\text { from the child. The situation results in } \\
\text { physical and mental stress for both the } \\
\text { child and the dentist. Physical restraint } \\
\text { (hold, arms, legs, head, etc.) is required, } \\
\text { the child may try to escape from the chair } \\
\text { and cover the mouth, and sometimes the } \\
\text { conclusion of the procedure becomes } \\
\text { impossible in one session. }\end{array}$ \\
\hline
\end{tabular}

OSUBRS scores are supposed to be assessed continuously, using specific software (Automated Counting System, JAGTECH, Rockville, MD). Because the software is no longer sold, we adapted a strategy in Microsoft Word for Windows 2010: While watching the videos, the observer continuously pressed a key when certain behaviors were observed, key 1 for OSUBRS score 1, and so on. After the observation of each film, the rater calculated the absolute and relative frequencies of occurrence for each of the four behavior codes.

Finally, at the end of each video observation, observers recorded the lone score for the Houpt overall behavior rating and the Brazilian-adapted Venham scale.

2.4. Statistical Analyzes. Sample size was estimated to be 23 and calculated in the website StatsToDo, establishing alpha at 0.05 and power at 0.80 and expecting a correlation coefficient (rho) of 0.5 .
Data presented a nonnormal distribution (Shapiro-Wilk test; $P>0.05$ ). The Spearman correlation test was used to verify the possible linear association among the continuous scores (percentages) of the Houpt categories and OSUBRS as well as the ordinal scores for Houpt overall behavior and Venham. The strength of the correlation coefficients was interpreted as suggested [28]: 0.00-0.30, negligible correlation; 0.20-0.50, low; 0.50-0.70, moderate; 0.70-0.90, high; $0.90-1.00$, very high.

Data were analyzed with SPSS version 19 (IBM Corp., Chicago, IL) and GraphPad Prism version 6 (and GraphPad Software, San Diego, CA). Significance was set at $P<0.05$.

\section{Results}

The average length of a dental sedation session was 43 minutes (minimum 33, maximum 66), totaling 1,209 minutes 
TABLE 4: Percentages of observed scores in children's behavior assessments.

\begin{tabular}{lcccc}
\hline \multirow{2}{*}{ Scales } & Scores & $\begin{array}{c}\text { Median } \\
(\%)\end{array}$ & \multicolumn{2}{c}{$98 \%$ confidence interval } \\
& 1 & 67.0 & 47.0 & 91.0 \\
& 2 & 6.5 & 1.4 & 14.0 \\
\multirow{3}{*}{ OSUBRS } & 3 & 1.9 & 1.1 & 3.1 \\
& 4 & 8.4 & 1.9 & 28.0 \\
\hline \multirow{3}{*}{ Houpt sleep } & 1 & 100 & 78.0 & 100 \\
& 2 & 0 & 0 & 17.0 \\
\hline \multirow{3}{*}{ Houpt } & 1 & 0 & 0 & 0 \\
movement & 2 & 0 & 0 & 33.0 \\
& 3 & 25.0 & 0 & 44.0 \\
& 4 & 44.0 & 30.0 & 75.0 \\
\hline \multirow{3}{*}{ Houpt crying } & 1 & 0 & 0 & 0 \\
& 2 & 13.0 & 0 & 29.0 \\
& 3 & 13.0 & 10.0 & 22.0 \\
& 4 & 50.0 & 33.0 & 88.0 \\
\hline
\end{tabular}

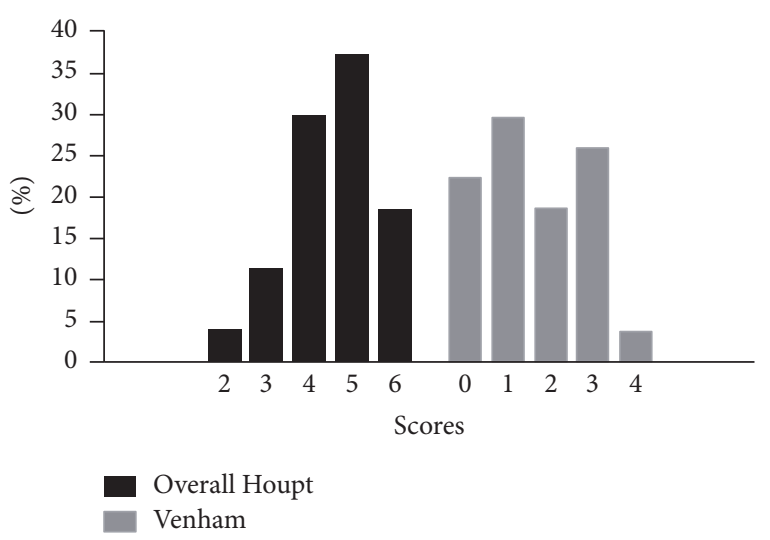

FIGURE 1: Frequency of children's overall behavior, according to the Houpt and Venham scales.

of observation of children's behavior in the digital archives of videos.

The scores observed most often for overall behavior were "very good" (Houpt) and "mild protest" (Venham) (Figure 1). Regarding detailed scores, children were mostly quiet (OSUBRS), awake/disoriented (Houpt sleep) with no movement, or crying (Houpt) (Table 4). During specific procedures, the most frequent Houpt scores were (see Figure 2) local anesthesia injection, awake, controllable movement and no crying; mouth prop insertion, awake, no movement and no crying; rubber dam placement, awake, no controllable movement and intermittent crying; handpiece use, awake, no movement and no crying; end of the session, awake, no movement and no crying.

Correlations among each investigated score varied from negligible to very high; some were statistically significant
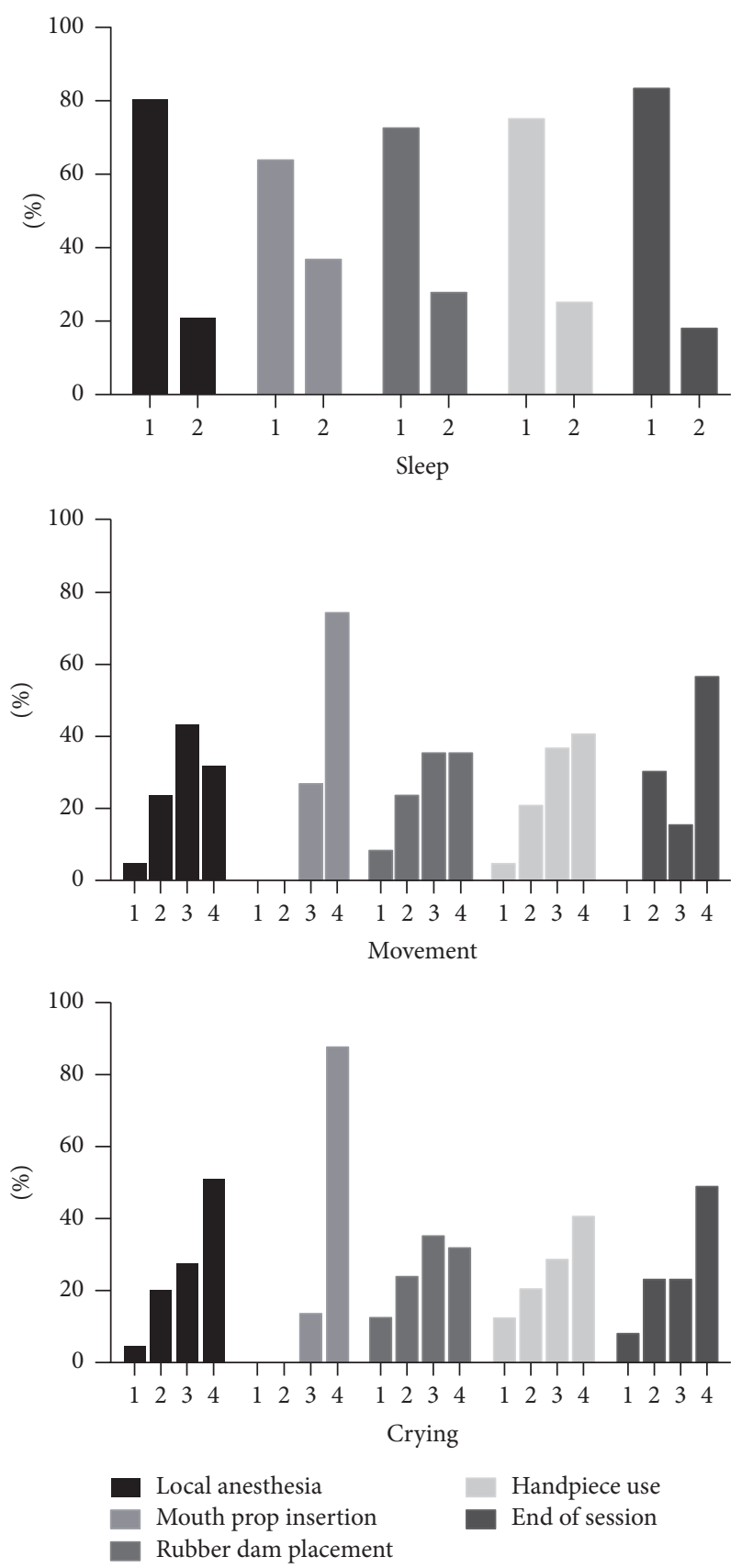

FIGURE 2: Frequency of children's behavior during specific dental procedures, according to the Houpt scale.

and others were not (Table 5). The Houpt overall behavior score and the Venham score had a high negative correlation $(P<0.001)$. These scores had high correlation coefficients if compared with OSUBRS scores 1 and 4 (Table 5). The Houpt overall behavior score showed moderate correlation with Houpt movement category scores of 2 and 4 and crying scores of 1,2, and 4 (Table 5). The Venham scores were highly correlated with Houpt movement score 4 and crying scores 2 and 4 and moderately correlated with Houpt movement score 2 and crying score 1 (Table 5). 


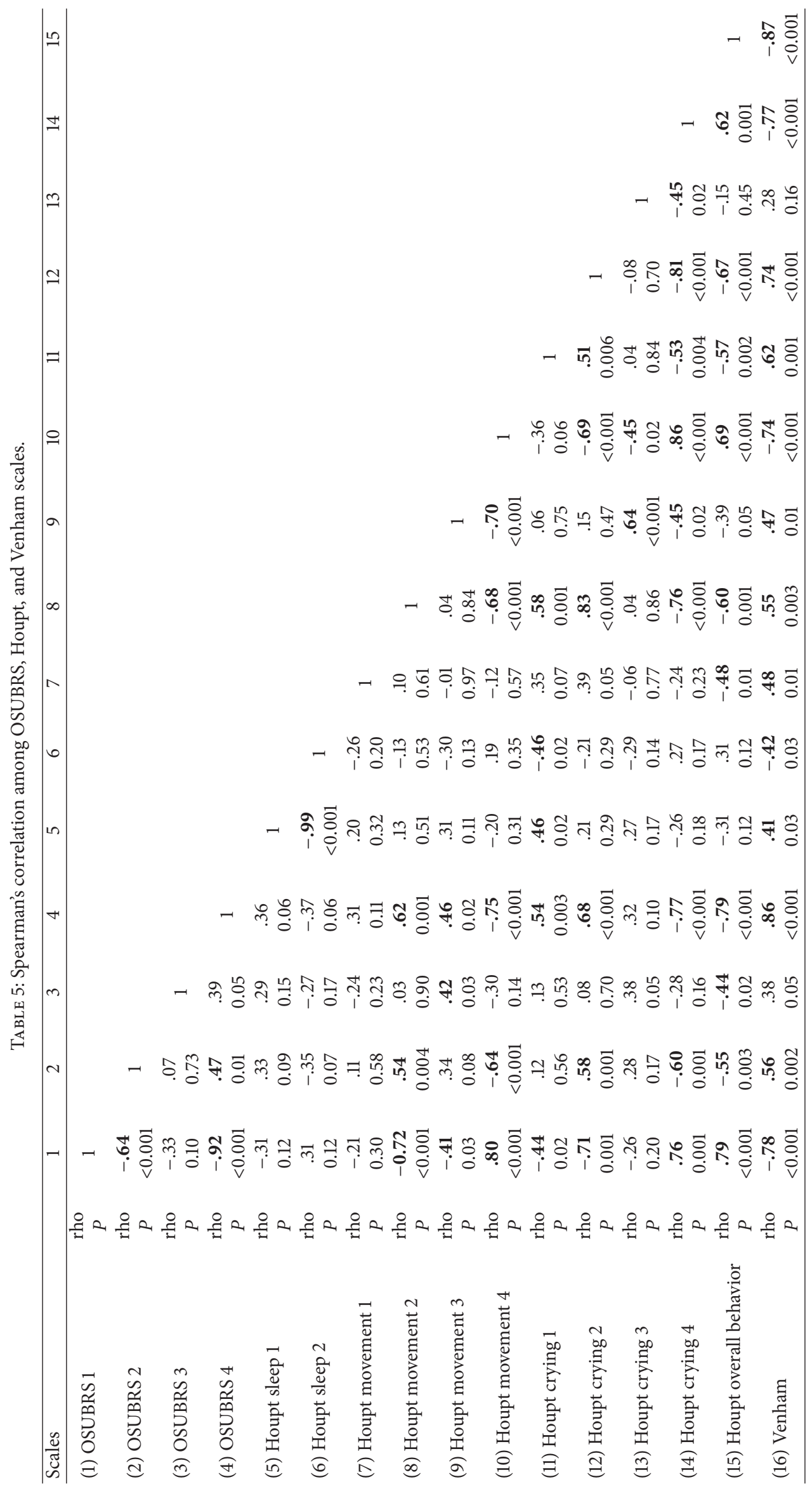




\section{Discussion}

Scales that assess children's behavior are an important tool in making decisions about behavioral management techniques in pediatric dentistry. One of the major findings of this study is that the global scales (Houpt and Venham) were highly correlated in their assessment of young children's behavior during dental sedation. These results indicate that the researcher or the clinician may choose either of the two scales for assessing a child's overall behavior. However, the restricted scales investigated (scores for Houpt categories and OSUBRS) showed a variety of relationships that should be discussed. To what extent will the use of a restricted scale add important information about the behavior of children during dental treatment?

Interestingly, Houpt overall behavior scores correlated highly with OSUBRS scores 1 (positive rho) and 4 (negative rho) but presented moderate correlations with the Houpt categories, showing positive correlations with the percentage of Houpt score 4 for movement and crying and negative correlations with Houpt scores 1 and 2 for crying and 2 for movement. While the Houpt overall behavior is one score that represents the child's complete reaction to the dental sedation appointment, OSUBRS measures behavior continuously and the Houpt scale categories assess specific moments in time. So, this intriguing strength of association probably means that OSUBRS was more precise in measuring behavior in this case. Also, Venham scores presented high correlations with OSUBRS scores 1 and 4, Houpt movement score 4, and Houpt crying scores 2 and 4. In all these cases, the direction of the linear relationships made sense.

The percentage of OSUBRS score 1 ("quiet") and score 4 ("struggling") had high positive or negative correlations with the percentages of Houpt movement and crying for score 4 , but not with score 1 for Houpt movement and crying. Most of our sample represented favorable behavior scores for OSUBRS (score 1) and for Houpt crying (score 4) and movement (score 4). That must have driven the statistical analysis to highlight the most relevant correlation coefficients for these scores. So, our results pertaining to OSUBRS score 3, Houpt movement for scores 1 and 2, and Houpt crying, score 1 should be interpreted with caution and will not be discussed further.

OSUBRS score 2 ("with crying, no movement") presented moderate negative correlation with the Houpt behaviors for "no movement" and "no crying" (score 4) and moderate positive correlation with score 2 for Houpt crying ("persistent crying"). One would not expect a negative correlation between OSUBRS score 2 and the Houpt movement score 4 because they represent behaviors without movement. Again, the explanation for this may be the most accurate continuous measurement using the OSUBRS scale discussed earlier in this section. Besides, OSUBRS score 2 presented a meaningful and moderate correlation with the score for Houpt overall behavior and the Venham scale.

The adaptation we did to assess the Houpt sleep category did not work well because it was not possible to assess "disorientation" separately from "fully awake." So, most children were identified as being awake/drowsy and just a few were assessed as sleeping. Further studies should consider using a video camera for close-ups of children's faces to allow better assessment in this category. Or, perhaps, the identification of children's sleep status would be better accomplished in situ rather than through videos.

According to the methodology of this study, only the Houpt scale allowed us to investigate the children's behavior during determined interventions during the dental sedation, and the mouth prop insertion was the most tolerable procedure among those investigated. So, if researchers want to investigate children's behavior related to a specific procedure, we agree with the literature that the Houpt scale is a good choice [25].

In addition, one of the advantages of the Houpt scale is the possibility of identifying the magnitude of movement or crying during dental sedation, which is not originally provided in OSUBRS [24]. In fact, this feature would be relevant for classifying sedation as successful or unsuccessful. Still, for the moderate sedation videos analyzed in this study, the most negative scores for motion and crying were uncommon; there were in-between behaviors that were scored as 2 or 3 on the Houpt scale. However, in general, these in-between scores correlated weakly with the global scales investigated, except for score 2 in the Houpt crying category and for the Venham scale score. Therefore, the role of assessing behavioral intensity during a sedative protocol that provides good success rates is questionable.

In this respect, one cannot forget that ketamine is a dissociative anesthetic. This sedative has an analgesic effect that dissociates the cerebral cortex, allowing a trance-like state with eyes open, but the child sees nothing and does not respond to painful stimuli [29]. All children included in this study received an association of oral midazolam and ketamine. Possibly, that is why we had a few observations of OSUBRS 3 and Houpt movement scores 1 and 2.

That being said, the most notable strengths of this study are the training of the observers, the use of standardized dental procedures, and the restricted age range of the children, which allowed us to control the scenario for video comparisons. The age range of children was restricted to 4-6 years to avoid interference from different stages of cognitive development on the sedation effectiveness as well as to represent the occurrence of caries in early childhood. Unfortunately, we were not able to use software to determine the OSUBRS scores according to the original idea, but the solution we found seemed reasonable. Anyway, as few studies have used the OSUBRS and still not following the recommendation of original use, the strategy used here may be helpful.

Also, the absence of a few scores in some categories made it difficult to analyze particular cases. Moreover, as our data followed a nonnormal distribution, we could not test the agreement of the scales with Bland-Altman curves, as previously suggested [25]. Another point is that the Houpt scale could be applied in dental clinics during sedation procedures [21], so the associations between Houpt scores reported in the dental setting and through video files should be evaluated in the near future. 
Ultimately, this study highlights the relevance of the properly assessment and register of children's behavior during dental sedation as is commonly done with vital signs. As the diversity of children's behavior rating scales recommended to pediatric procedural sedation can hinder the professional's choice on which one to use, this study in the dental context serves as a model for other health professionals who provide sedation for children in an outpatient basis.

\section{Conclusions}

To sum up, this study shows that Houpt, OSUBRS, and Venham scales are appropriate to monitor children's behavior during pediatric dental sedation. The Houpt overall behavior scale and the Venham scale are reasonable choices for the clinical routine of busy professionals. In the research context, continuous assessment with OSUBRS through videos has a chance to give more precise data, while the Houpt categories can easily demonstrate children's behavior during procedures.

\section{Competing Interests}

The authors declare that they have no competing interests.

\section{Acknowledgments}

The authors appreciate the financial support from the National Council for Scientific and Technological Development $(\mathrm{CNPq})$, the Coordination for the Improvement of Higher Education Personnel (CAPES), and the State of Goias Research Foundation (FAPEG).

\section{References}

[1] L. Toomarian, K. Salem, and G. Ansari, "Assessing the sedative effect of oral vs submucosal meperidine in pediatric dental patients," Dental Research Journal, vol. 10, no. 2, pp. 173-179, 2013.

[2] R. K. Pandey, S. K. Bahetwar, A. K. Saksena, and G. Chandra, "A comparative evaluation of drops versus atomized administration of intranasal ketamine for the procedural sedation of young uncooperative pediatric dental patients: a prospective crossover trial," Journal of Clinical Pediatric Dentistry, vol. 36, no. 1, pp. 79-84, 2011.

[3] P. Malhotra, S. Thakur, P. Singhal et al., "Comparative evaluation of dexmedetomidine and midazolam-ketamine combination as sedative agents in pediatric dentistry: a double-blinded randomized controlled trial," Contemporary Clinical Dentistry, vol. 7, no. 2, pp. 186-192, 2016.

[4] D. Flores-Castillo, R. Martínez-Rider, S. Ruiz-Rodríguez, A. Garrocho-Rangel, J. Lara-Guevara, and A. Pozos-Guillén, "Subcutaneous midazolam with and without ketamine for sedation in children undergoing dental treatment: a pilot study," The Journal of Clinical Pediatric Dentistry, vol. 39, no. 4, pp.382-386, 2015.

[5] K. Salem, S. Kamranzadeh, M. Kousha, S. Shaeghi, and F. AbdollahGorgi, "Two oral midazolam preparations in pediatric dental patients: a prospective randomised clinical trial," International Journal of Pediatrics, vol. 2015, Article ID 349795, 7 pages, 2015.
[6] G. M. Mahmoud and I. A. E. F. Haggag, "Comparison of dexmedetomidine and midazolam for conscious sedation in pediatric dental patients: a clinical randomized trial," Journal of American Science, vol. 10, pp. 300-308, 2014.

[7] M. F. Ghajari, M. V. Golpayegani, M. Bargrizan, G. Ansari, and S. Shayeghi, "Sedative effect of oral midazolam/hydroxyzine versus chloral hydrate/hydroxyzine on 2-6 year-old uncooperative dental patients: a randomized clinical trial," Journal of Dentistry (Tehran), vol. 11, pp. 93-99, 2014.

[8] M. Natarajan Surendar, R. Kumar Pandey, A. Kumar Saksena, R. Kumar, and G. Chandra, "A comparative evaluation of intrnasal dexmedetomidine, midazolam and ketamine for their sedative and analgesic properties: a triple blind randomized study," Journal of Clinical Pediatric Dentistry, vol. 38, no. 3, pp. 255-261, 2014.

[9] S. A. Sheta, M. A. Al-Sarheed, and A. A. Abdelhalim, "Intranasal dexmedetomidine vs midazolam for premedication in children undergoing complete dental rehabilitation: a double-blinded randomized controlled trial," Paediatric Anaesthesia, vol. 24, no. 2, pp. 181-189, 2014.

[10] I. D. Azevedo, M. A. F. Ferreira, A. P. S. Da Costa, V. L. Bosco, and R. D. Moritz, "Efficacy and safety of midazolam for sedation in pediatric dentistry: a controlled clinical trial," Journal of Dentistry for Children, vol. 80, no. 3, pp. 133-138, 2013.

[11] R. Chopra, M. Mittal, K. Bansal, and P. Chaudhuri, "Buccal midazolam spray as an alternative to intranasal route for conscious sedation in pediatric dentistry," Journal of Clinical Pediatric Dentistry, vol. 38, no. 2, pp. 171-173, 2013.

[12] N. Mittal, A. Goyal, K. Gauba, A. Kapur, and K. Jain, "A double blind randomized trial of ketofol versus propofol for endodontic treatment of anxious pediatric patients," Journal of Clinical Pediatric Dentistry, vol. 37, no. 4, pp. 415-420, 2013.

[13] T. A. Moreira, P. S. Costa, L. R. Costa et al., "Combined oral midazolam-ketamine better than midazolam alone for sedation of young children: a randomized controlled trial," International Journal of Paediatric Dentistry, vol. 23, no. 3, pp. 207-215, 2013.

[14] P. Tyagi, S. Tyagi, and A. Jain, "Sedative effects of oral midazolam, intravenous midazolam and oral diazepam in the dental treatment of children," Journal of Clinical Pediatric Dentistry, vol. 37, no. 3, pp. 301-306, 2013.

[15] V. Collado, D. Faulks, E. Nicolas, and M. Hennequin, "Conscious sedation procedures using intravenous midazolam for dental care in patients with different cognitive profiles: a prospective study of effectiveness and safety," PLOS ONE, vol. 8, no. 8, Article ID e71240, 2013.

[16] S. Bhatnagar, U. M. Das, and G. Bhatnagar, "Comparison of oral midazolam with oral tramadol, triclofos and zolpidem in the sedation of pediatric dental patients: an in vivo study," Journal of Indian Society of Pedodontics and Preventive Dentistry, vol. 30, no. 2, pp. 109-114, 2012.

[17] M. Guelmann, R. Brackett, N. Beavers, and R. E. Primosch, "Effect of continuous versus interrupted administration of nitrous oxide-oxygen inhalation on behavior of anxious pediatric dental patients: a pilot study," Journal of Clinical Pediatric Dentistry, vol. 37, no. 1, pp. 77-82, 2012.

[18] M. Somri, C. A. Parisinos, J. Kharouba et al., "Optimising the dose of oral midazolam sedation for dental procedures in children: a prospective, randomised, and controlled study," International Journal of Paediatric Dentistry, vol. 22, no. 4, pp. 271-279, 2012.

[19] S. K. Bahetwar, R. K. Pandey, A. K. Saksena, and C. Girish, "A comparative evaluation of intranasal midazolam, ketamine 
and their combination for sedation of young uncooperative pediatric dental patients: a triple blind randomized crossover trial," Journal of Clinical Pediatric Dentistry, vol. 35, no. 4, pp. 415-420, 2011.

[20] A. Shabbir, S. Bhat, H. Sundeep, and S. M. Salman, "Comparison of oral Midazolam and triclofos in conscious sedation of uncooperative children," Journal of Clinical Pediatric Dentistry, vol. 36, no. 2, pp. 189-196, 2011.

[21] M. I. Houpt, N. J. Weiss, S. R. Koenigsberg, and P. J. Desjardins, "Comparison of chloral hydrate with and without promethazine in the sedation of young children," Pediatric Dentistry, vol. 7, no. 1, pp. 41-46, 1985.

[22] M. E. Lochary, S. Wilson, A. L. Griffen, and D. L. Coury, "Temperament as a predictor of behavior for conscious sedation in dentistry," Pediatric Dentistry, vol. 15, no. 5, pp. 348-352, 1993.

[23] L. L. Venham, E. Gaulin-Kremer, E. Muster, D. Bengston-Audia, and J. Cohan, "Interval rating scales for children's dental anxiety and uncooperative behavior," Pediatric Dentistry, vol. 2, no. 3, pp. 195-202, 1980.

[24] S. Wilson, "A review of important elements in sedation study methodology," Pediatric Dentistry, vol. 17, no. 7, pp. 406-412, 1995.

[25] M. T. Hosey and A. S. Blinkhorn, "An evaluation of four methods of assessing the behavior of anxious child dental patients," International Journal of Paediatric Dentistry, vol. 5, no. 2, pp. 87-95, 1995.

[26] D. D. Torriani, A. M. Teixeira, R. Pinheiro, M. L. Goettems, and M. L. M. Bonow, "Adaptação transcultural de instrumentos para mensurar ansiedade e comportamento em clínica odontológica infantil," Arquivos em Odontologia, vol. 44, pp. 17-23, 2008.

[27] L. Lourenço-Matharu, P. F. Ashley, and S. Furness, "Sedation of children undergoing dental treatment," Cochrane Database of Systematic Reviews, no. 3, Article ID CD003877, 2012.

[28] M. M. Mukaka, "Statistics corner: a guide to appropriate use of correlation coefficient in medical research," Malawi Medical Journal, vol. 24, no. 3, pp. 69-71, 2012.

[29] J. D. Tobias, "Sedation in the pediatric intensive care unit: challenges, outcomes, and future strategies in the United States," in Pediatric Sedation Outside of the Operating Room, K. Mason, Ed., pp. 275-328, Springer, New York, NY, USA, 2nd edition, 2001. 


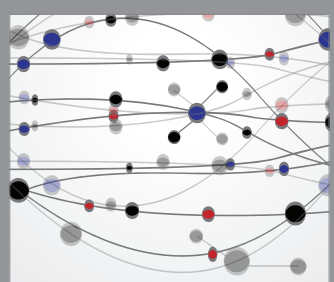

The Scientific World Journal
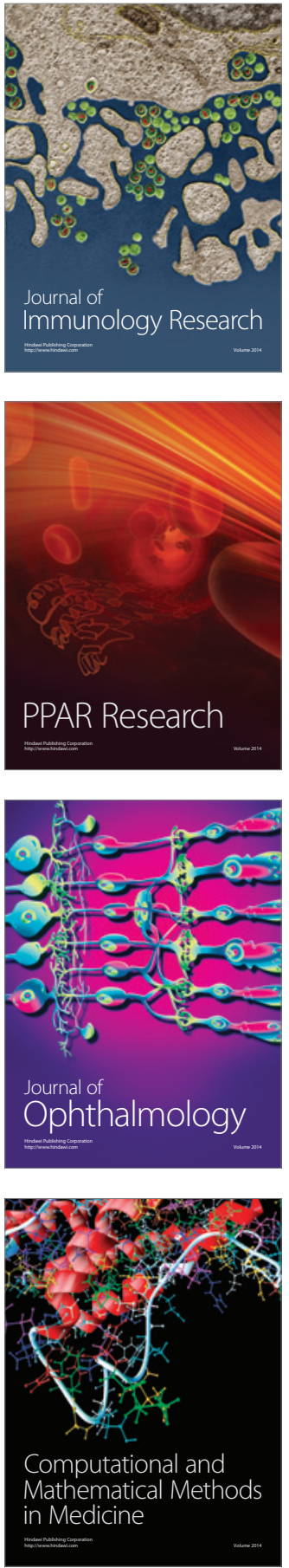

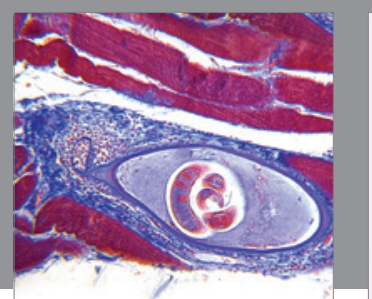

Gastroenterology Research and Practice

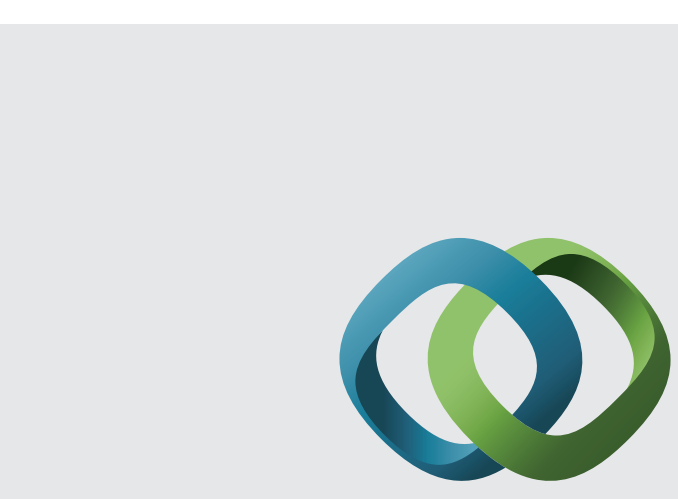

\section{Hindawi}

Submit your manuscripts at

http://www.hindawi.com
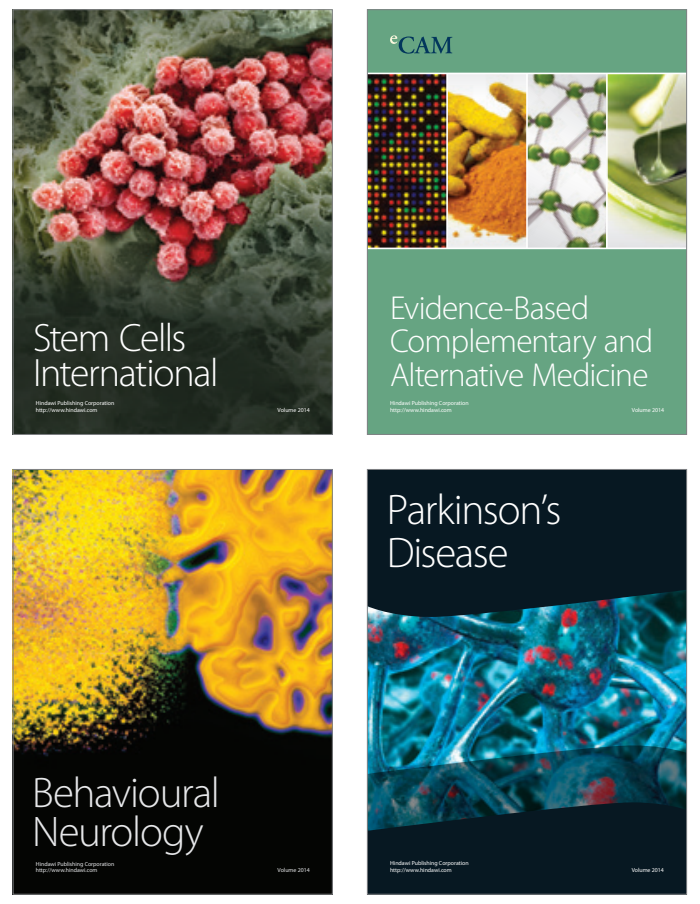
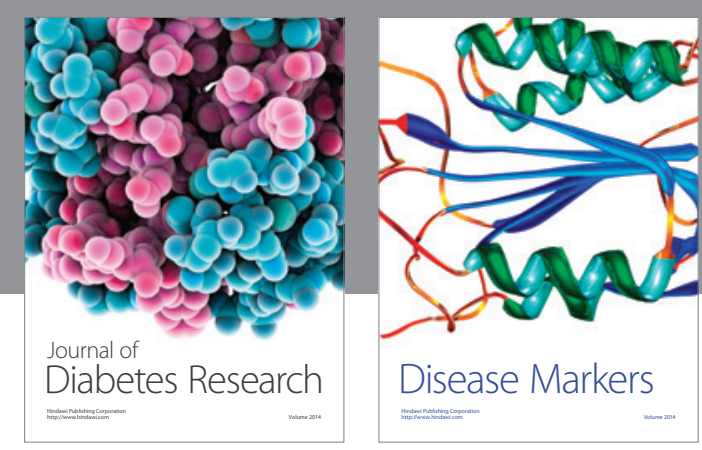

Disease Markers
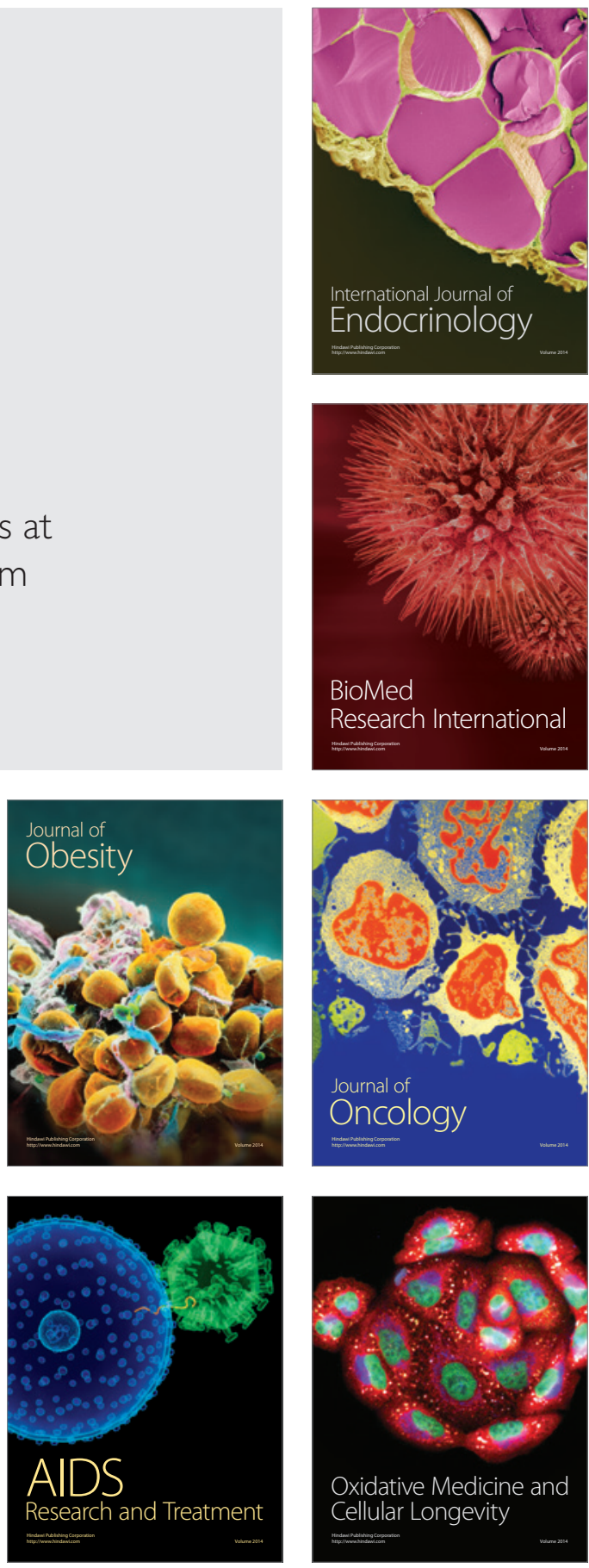